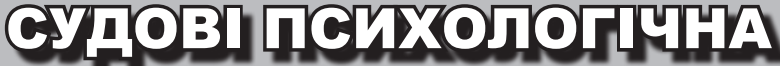

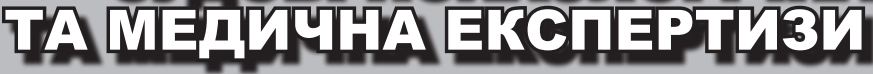

DOI: https://doi.org/10.32353/khrife.2018.64

УДК 343.98:63

T. M. Сгорова, завідувач сектору Полтавського відділення Харківського НДІСЕ

E-mail: tet-egorova@meta.ua,

С. Г. Мороз, завідувач Полтавського відділення Харківського НДІСЕ

\section{ЩОДО МОЖЛИВОСТЕЙ СУДОВО-ПСИХОЛОГІЧНОЇ ЕКСПЕРТИЗИ ПОТЕРПІЛИХ ЗА ЗЛОЧИНАМИ, ПОВ'ЯЗАНИМИ ІЗ ТОРГІВЛЕЮ ЛЮДЬМИ}

Розглянуто правові підстави та теоретико-методичні питання щодо проведення судово-психологічної експертизи потерпілих при розслідуванні кримінальних правопорушень, передбачених ст. 149 КК Украӥни. Визначено психологічні підстави для правової кваліфікачії уразливого стану потерпілих, предмет, об'єкт і основні завдання в аспектах наукової психології й судової експертологї.

Ключові слова: торгівля людьми, експертна практика, особистість, діяльність, вольовий акт, психологічна уразливість, психологічна залежність, експертна методика.

Конституція України визнає й гарантує основні права, свободи та обов'язки людини й громадянина відповідно до загальновизнаних норм міжнародного права. Статтею 21 Конституції України проголошено право всіх людей на вільність і рівність у своїй гідності та правах, які $є$ невідчужуваними й непорушними; ст. 23 закріплено право людини на вільний розвиток своєї особистості, якщо при цьому не порушуються права й свободи інших людей та обов'язки перед суспільством, у якому забезпечується вільний і всебічний розвиток ії особистості; ст. 33 гарантується право людини на свободу пересування, вільний вибір місця проживання, право вільно залишати територію України; ст. 43 закріплено право кожної людини на працю, яку вона вільно обирає або на яку вільно погоджується, використання примусової праці забороняється.

Проте, незважаючи на гарантії міжнародно-правових приписів, сучасний стан кримінальних правопорушень має світову тенденцію до зростання торгівлею людьми, яка здійснюється переважно транснаціональною організованою злочинністю. Цей вид злочинів за останнє десятиріччя набув масштабу, що загрожує національній безпеці будь-якої держави. 
Україна першою серед пострадянських держав визнала проблему торгівлі людьми як одну із найбільш небезпечних для суспільства, увівши в 1998 р. до Кримінального кодексу України (КК України) ст. 124리 («оргівля людьми»). У 2001 р. був прийнятий новий Кримінальний кодекс України, у якому ст. 149 («Торгівля людьми або інша незаконна угода щодо людини») діяння проти свободи, зведення цінності особистості до рівня ії матеріальної оцінки, продаж та купівля людини визнані тяжким злочином проти особистості ${ }^{1}$.

За даними ОБСЄ, торгівля людьми в Україні стрімко зростає, що викликано низкою соціально-економічних i, певною мірою, політичних причин, до яких належать: тяжке економічне положення громадян і безробіття; недостатня поінформованість щодо можливостей працевлаштування за кордоном; попит на дешеву робочу силу закордоном та нелегальна трудова міграція; активна діяльність злочинних угрупувань і недостатність переслідування торговців людьми; насильство в сім’ї; корупція; військові конфлікти ${ }^{2}$.

У 2011 р. прийнято Закон України «Про протидію торгівлі людьми», яким визначаються організаційно-правові засади протидії торгівлі людьми, гарантії гендерної рівності, основні напрями державної політики та засади міжнародного співробітництва в цій сфері, порядок установлення статусу осіб, які постраждали від торгівлі людьми, та порядок надання допомоги таким особам ${ }^{3}$.

Виходячи зі змісту ст. 149 КК України, основним безпосереднім об'єктом злочину є посягання на волю й гідність людини, яке підлягає доказуванню. Згідно з прим. 2 до ст. 149 однією із кваліфікуючих ознак цього виду правопорушень $є$ уразливий стан потерпілої особи, який зумовлений фізичними чи психічними властивостями або зовнішніми обставинами, що позбавляють або обмежують іiї здатність усвідомлювати свої дії (бездіяльність) або керувати ними, приймати за своєю волею самостійні рішення, чинити опір насильницьким чи іншим незаконним діям, збіг тяжких особистих, сімейних або інших обставин.

У дослідженнях вітчизняних спеціалістів зазначається, що соціальнопсихологічні фактори, які сприяють торгівлі людьми, мають суттєве значення. Дослідниками юристами, соціологами, психологами та іншими визначено категорії населення України, які є найбільш уразливими до торгівлі людьми, а саме: незаміжні жінки у віці 18-26 років (як потенційні жертви сексуальної експлуатації), які мають низький та дуже низький рівень матеріального забезпечення; чоловіки у віці 31-60 років, перш за все - одружені,

1 Кримінальний кодекс України : Закон України від 05.04.2001 № 2341-III (у ред. від 10.06.2018). URL: http://zakon3.rada.gov.ua (дата звернення: 14.05.2018).

2 Освещение в средствах массовой информации проблемы торговли людьми. Пособие для журналистов / OSCE. Киев : Интертехнология, 2007. URL: https:/www. osce.org. ru (дата звернення: 26.05.2018).

3 Про протидію торгівлі людьми : Закон України від 20.09.2011 № 3739-VI. Відом. Верхов. Ради Украӥни. 2012. № 19-20. С. 173. 
які уразливі до трудової експлуатації; діти (переважно дівчатка) у віці 1318 років із неповних і реструктурованих сімей ${ }^{1}$.

На думку О. В. Ковальової, найбільш важливим є вивчення соціальнопсихологічних чинників у сфері торгівлі людьми. Вона виділяє уразливі групи населення, стосовно яких існує висока ймовірність стати об'єктами цього злочину, і зауважує, що такі групи не є статичними, оскільки політична та економічна ситуації в Україні змінюються. О. В. Ковальова виділяє нову групу ризику для України - внутрішньо переміщені особи із зони конфлікту ${ }^{2}$.

Як зазначає А. М. Орлеан, поняття уразливого стану, визначеного в прим. 2 до ст. 149 КК України, є юридичною категорією. Автор виділяє уразливий стан двох видів: фізіологічний і соціальний. Фізіологічний уразливий стан зумовлений фізичними чи психічними властивостями або зовнішніми обставинами, стан особи, який позбавляє або обмежує їі здатність усвідомлювати свої дії (бездіяльність) або керувати ними, приймати за своєю волею самостійні рішення, чинити опір насильницьким чи іншим незаконним діям; може бути викликаний психічними властивостями (наявність певних захворювань, розладів або відхилень у психічній діяльності тощо), фізичними властивостями (неможливість чинити опір незаконним діям через фізичну хворобу, певні фізичні вади тощо) та певними зовнішніми факторами (наприклад, приведенням особи до несвідомого стану шляхом застосування снодійних чи наркотичних засобів). На думку А. М. Орлеана, наявність або відсутність фізіологічного уразливого стану потерпілого та його використання обвинуваченим під час учинення злочину можуть (проте не обов'язково) бути підтвердженими результатами медичної, психологічної, психіатричної або комплексної експертизи потерпілого. До соціального виду уразливого стану автор відносить сукупність таких обставин, що змушує людину погодитися бути експлуатованою. При цьому для соціального уразливого стану не $є$ характерним обмеження здатності особи усвідомлювати свої дії, керувати ними та чинити опір неправомірному впливу. А. М. Орлеан зауважує, що наявність соціального уразливого стану має, насамперед, підтверджуватися не результатами експертиз, а сукупністю доказів існування низки тяжких особистих сімейних або інших обставин ${ }^{3}$.

На нашу думку, позиція А. М. Орлеана щодо проведення судової експертизи (зокрема, психологічної) із метою встановлення наявності або від-

1 Соціальний аналіз основних чинників торгівлі людьми: реальна ситуація та шляхи запобігання : монографія / А. В. Алексєєва, Ю. М. Галустян, К. Б. Левченко та ін. Київ, 2003. 91 с.

2 Ковальова O.B. Попередження як напрям протидії торгівлі людьми. Протидія незаконній міграції та торгівлі людьми : матеріали Міжнар. наук.-практ. симпозіуму, м. Івано-Франківськ, 11-12 берез. 2016 р. Івано-Франківськ : РВ Івано-Франків. ун-ту права ім. Короля Данила Галицького, 2016. С. 67-70.

Орлеан А. М. Ознаки складу злочину «Торгівля людьми або інша незаконна угода щодо людини», які потребують найбільшої уваги під час практичного застосування цієї норми. Там само. С. 112-116. 
сутності уразливого стану потерпілого $є$ цілком доцільною. Проте не можна погодитися з виділенням А. М. Орлеаном двох видів уразливого стану потерпілих (фізіологічного та соціального), оскільки будь-яка діяльність особистості реалізується за конкретних соціальних умов і супроводжується певним психічним станом. Тому соціально-психологічні фактори, що можуть зумовити уразливий стан людини, $є$ цілісним, багатомірним феноменом.

Як випливає з прим. 2 до ст. 149 КК України, юридичні ознаки уразливого стану потерпілої особи співвідносяться із соціально-психологічними параметрами, що характеризують психічну діяльність особи, обмежуючи іiі здатність повною мірою усвідомлювати характер своїх дій, повною мірою передбачати їх наслідки й керувати ними та приймати самостійне рішення. Тобто в психологічному сенсі уразливий стан особи передбачає ії залежність від когось (інших осіб) або чогось (життєвих обставин), що, з правової точки зору, надає іншій людині можливість маніпулювати потерпілим, учиняючи на нього психологічний вплив.

Об'єктом судово-психологічної експертизи (дослідження) потерпілих у справах, пов'язаних із торгівлею людьми, є людина як особистість, i джерела інформації, що містять відомості про психічну діяльність потерпілого за юридично значимих обставин.

Предметом судово-психологічного дослідження (експертизи) потерпілих у справах, пов'язаних із торгівлею людьми, є специфіка вольової регуляції діяльності, яка має суттєве значення при прийнятті життєво важливого рішення.

Оскільки правове поняття «уразливий стан» $є$ оціночним, завданнями цього виду дослідження $\epsilon$ встановлення індивідуально-психологічних особливостей особистості потерпілого, його мотиваційної сфери, інтелектуальної та емоційно-вольової сфер, особливостей діяльності в ситуації зазначеного правопорушення, та інших психологічних факторів, які можуть бути преморбідом для формування в нього залежності від іншої особи або певних життєвих обставин, маніпулювання вольовою діяльністю потерпілого при прийнятті ним життєво важливого рішення, певною мірою обмежуючи регуляцію його діяльності. У ході вирішення цих завдань аналізуються провідні індивідуально-психологічні та мотиваційні чинники потерпілої особи, що вплинули на їі діяльність у юридично значимій ситуації. Установлюються відповідність пропозиції обвинуваченого провідним потребам потерпілого, його індивідуально-психологічним особливостям, наявній життєвій ситуації та ступеня соціалізації; визначається специфіка усвідомлення потерпілим зазначеної пропозиції як прийнятної, що є слабкими (уразливими) ланками в структурі особистості потерпілого при прийнятті життєво важливого рішення та полегшують (або можуть полегшити) свідомий вибір на користь пропозиції обвинуваченої особи.

Психологічний аналіз реалізації вибору потерпілого на користь пропозиції обвинуваченого полягає у встановленні підпорядкування його діяльності провідній потребі в певному заробітку, ступеня ініціативності, активності, багатоетапності, низки зусиль, що властиві для складної вольової діяльності. 
У результаті психологічного дослідження встановлюється ступінь усвідомленої діяльності потерпілого, що має (або не має) усі необхідні ознаки складної вольової поведінки.

На користь актуальності проведення судово-психологічної експертизи при розслідуванні правопорушень, пов'язаних із торгівлею людьми або з іншими незаконними угодами щодо людини, свідчить зростання попиту з боку правоохоронних органів і суду стосовно проведення досліджень цього виду. Зокрема, починаючи з 2010 р., судово-слідчі органи активно призначають судово-психологічні експертизи за кримінальними справами, пов'язаними із сексуальною експлуатацією людини або її використанням у порнобізнесі, із примусовою працею людини, рабством, залученням у боргову кабалу, усиновленням (удочерінням) із метою наживи, утягненням у злочинну діяльність, використанням у збройних конфліктах тощо. Ця тенденція, з урахуванням транснаціональної специфіки розслідування злочинів, передбачених ст. 149 КК України, має перспективи до зростання.

Проте нині проведення судово-психологічних експертиз, призначених за кримінальними провадженнями, передбаченими ст. 149 КК України, виконується за умов відсутності відповідної експертної методики та нерозробленості теоретико-методичних аспектів, що мають бути покладені в основу цього виду психологічного дослідження. У Полтавському відділенні Харківського НДІ судових експертиз ім. Засл. проф. М. С. Бокаріуса вперше створюється методика судово-психологічної експертизи потерпілих при розслідуванні правопорушень, пов'язаних із торгівлею людьми або з іншими незаконними угодами стосовно людини, яка має на меті розроблення уніфікованих алгоритмів експертного дослідження.

\section{О ВОЗМОЖНОСТЯХ СУДЕБНО-ПСИХОЛОГИЧЕСКОЙ ЭКСПЕРТИЗЫ ПОТЕРПЕВШИХ ПО ПРЕСТУПЛЕНИЯМ, СВЯЗАННЫМ С ТОРГОВЛЕЙ ЛЮДЬМИ}

\section{Егорова Т. М., Мороз С. $Г$.}

Рассмотрена проблема торговли людьми, имеющая транснациональный, масштабный характер и угрожающая нащиональной безопасности государств. Приведены данные OSCE, в которых указано на ряд сочиально-экономических и политических факторов, обусловливающих рост торговли людьми в Украине. В обзоре основных законодательных актов Украины указано на организационно-правовой регламент противодействия торговле людьми, на направления государственной политики и международного сотрудничества. Рассмотрены исследования украинских специиалистов, изучающих социильно-психологические факторы, которые могут иметь существенное значение для преступлений, связанных с торговлей людьми. Определены объект, предмет и задачи судебно-психологического исследования потерпевших по преступлениям, подпадающим под действие ст. 149 УК Украины. Проведен анализ примечания $2 \kappa$ этой статье с позиций правовых (квалифицирующих) признаков уязвимого состояния потерпевщего лица, а также с позиций научной психологии и судебно-психологической экспертизы. В частности, поскольку правовое понятие «уязвимое состояние» относится к категории оценочных, заданиями психологического исследования являются установление инди- 
видуально-психологических особенностей личности потерпевщего, специфики его мотивационной, интеллектуальной и эмоциональной сфер, особенностей деятельности в ситуачии данного правонарушения, а также иных психологических факторов, которые могут быть преморбидом для формирования зависимости от иной особы либо от определенных жизненных обстоятельств, которые могут создавать благоприятные условия для манипулирования сознанием и волевой деятельностью потерпевшего при принятии жизненно важного решения, ограничивая регуляиию его деятельности. Результатом психологического исследования является установление степени осознанной деятельности потерпевщего, имеющей (либо не имеющзей) все необходимые признаки сложного волевого поведения. С учетом актуальности данной тематики и ростом запросов судебно-следственных органов на проведение соответствующих психологических экспертиз в Полтавском отделении Харьковского НИИСЭ разрабатывается соответствующая экспертная методика психологического исследования.

Ключевые слова: торговля людьми, экспертная практика, личность, деятельность, волевой акт, психологическая уязвимость, психологическая зависимость, экспертная методика.

\title{
ABOUT POSSIBILITIES OF FORENSIC PSYCHOLOGY EXAMINATION ON THE VICTIMS OF CRIMES RELATED TO HUMAN TRAFFICK
}

\author{
Ehorova T. M., Moroz, S. G.
}

The problem of human traffick is transnational, wide-ranging character and threatens national security of states is considered. The OSCE data indicating a number of socioeconomic and political factors that cause the growth of human traffick in Ukraine are presented. In the review of the main legislative acts of Ukraine the organizational and legal regulation of counteraction to human traffick, directions of public policy and international cooperation are denoted. Researches of Ukrainian experts studying socio-psychological factors that may be of significant importance for crimes related to human traffick are considered. Object, subject and tasks of the forensic psychological research on the victims of crimes falling within the scope of Art. 149 of the Criminal Code of Ukraine. Analysis of note 2 to this article was performed from the positions of legal (qualifying) signs of the vulnerable state of the injured person, as well as from the standpoints of scientific psychology and forensic psychological examination. In particular, since the legal concept of "vulnerable state" refers to the category of appraisal, the tasks of psychological research are determination of individual psychological characteristics of victim's personality, specifics of his motivational, intellectual and emotional spheres, specific activities in the situation of the particular offense, and other psychological factors that may be premorbidity for the formation of dependence on another person or on certain life circumstances that can create favorable conditions for manipulating the consciousness and volitional activity of victim while making a vital decision, limiting the regulation of his activities. Result of psychological research is a degree determination of victim conscious activity who has (or does not have) all the necessary signs of complex volitional behavior. Corresponding expert methodology for psychological research is being developed taking into account the relevance of this topic and increasing requests of judicial investigating bodies to perform appropriate psychological examinations at Poltava branch of the KhRIFE.

Keywords: human traffick, forensic practice, personality, activity, volitional act, psychological vulnerability, psychological dependence, expert methods. 